\title{
Traditional Sustained Yield Management: Problems and Alternatives ${ }^{1}$
}

\author{
by
}

\author{
Dr. John L. Walker ${ }^{2}$
}

\begin{abstract}
Sustained yield has been a tenet of faith among foresters since forestry emerged as a profession. The concept developed during feudal times when foresters were primarily gamekeepers for landed aristocracy. When the industrial revolution put new demands on forests for fuelwood, foresters extended their "bag limits" to the trees, based on the perception that unregulated markets would result in forest devastation. Early foresters believed that governments must own or regulate forests to perpetuate timber resources. This belief is the basis for extensive public forests today in Canada, the United States and elsewhere. The vision of the early foresters was not reality, but many still cling to their erroneous notions.

Markets can and do provide far better information than any sustained yield model about how forests should be managed. Net present value maximization without any sustained yield harvest flow constraints provides a superior way to manage forests and subjects the vision needed to plan for today and tomorrow to meaningful reality checks. Sustained yield constraints greatly distort attempts to measure the effects of alternative management practices for both timber and non-timber outputs.
\end{abstract}

\section{Résumé}

Le rendement soutenu est devenu un credo de foi parmi les forestiers depuis que la foresterie a été reconnue comme une profession. Le concept a été développé à l'époque féodale alors que les forestiers étaient principalement des garde-chasses pour l'aristocratie terrienne. Lorsque la révolution industrielle excerça de nouvelles demandes sur les forêts sous la forme de bois de combustion, les forestiers étendirent leurs "responsabilités" aux arbres, en se basant sur la perception que les marchés non régis provoqueraient la dévastation des forêts. Les premiers forestiers croyaient que les gouvernements devaient posséder ou régulariser les forêts afin de perpétuer les ressources ligneuses. Cette croyance est à la base des forêts extensives publiques du Canada, des EtatsUnis et de d'autres pays. La vision des premiers forestiers n'était pas la réalité, mais plusieurs continuent de se cramponner à ces notions erronnées.

Les marchés peuvent et doivent procurer une bien meilleure information que tout modèle de rendement soutenu en ce qui a trait à l'aménagement des forêts. La maximalisation de la valeur actuelle nette sans aucune contrainte de flot de récolte basée sur le rendement soutenu constitue une façon plus adéquate d'aménager les forêts et assujettit la vision nécessaire pour planifier pour aujourd'hui et demain à des vérifications pleines de bon sens. Les contraintes de rendement soutenu distordent grandement les tentatives de mesurer les effets des pratiques possibles d'aménagement autant pour les valeurs ligneuses que non ligneuses.

\section{Introduction}

Sustained yield has been a tenet of faith among foresters since forestry emerged as a profession. In some circles it has been elevated to the level of other unassailable institutions such as motherhood, democracy and religious freedom. My purpose on this panel is to review some serious problems with the concept and offer an alternative.

In the United States, forestry emerged as a profession and national forests were created based on the belief that unregulated markets would result in forest devastation. It was believed governments must own or regulate forests to perpetuate timber resources. This belief is still widely held and is the basis for extensive public forest ownerships in Canada, the United States and elswhere.

The profession of forestry began somewhere in Germany several centuries ago. Prior to the industrial revolution, forest management practised by professional foresters had spread from Germany to most other parts of Europe. The origin and

\footnotetext{
TPaper given at the CIF Annual Meeting, Kananaskis Village, Alberta, 18 October 1989
} ${ }^{2}$ Vice President, Land and Timber, Simpson Timber Company. Seattle, Washington spread of forestry in the past are veiled by time, language barriers and innumerable wars and other major societal changes. A common forest management philosophy emerged in this environment that continues to have a major and most unfortunate impact on forestry today, not just in Europe, or in the United States or Canada, but throughout the world. This philosophy is capsulized by the concept of sustained yield and the many associated ideas about how forests should be managed. Sustained yield is a biological model and a philosophy of forest management that is based on few, if any, economic concepts. It is incompatible with the generally accepted role of prices in modern market economies to best allocate society's scarce resources.

\section{Sustained Yield}

Sustained yield can be given different definitions to suit the objectives of various users. It is usually more expedient for a user to define the concept to fit a particular circumstance or objective than to challenge it. Consequently, most public and private forest management organizations are quick to volunteer that they are practising sustained yield. The term is sometimes used more as a slogan, and not given any 
precise operational definition. At Simpson, for example, one of my earliest contributions was to change the definition of sustained yield used in the company's public affairs booklet entitled "This Is Simpson", from a more traditional definition that implied evenflow to one that was more in keeping with actual practices and policies. The new definition reads as follows:

"In managing our lands, Simpson operates on a sustained yield basis. The exact forest planning systems involved are complex, but the concept itself is quite simple.

Sustained yield means maintaining continuous production on all our lands that are economically and environmentally suited for timber production. Mature timber is harvested at rates consistent with both available supplies and market demands."

Those of you who are more in tune with a traditional definition of sustained yield may be quick to point out the Simpson definition provides quite a bit of wiggle room by leaving some key elements unspecified. This was done intentionally to help wean the company, its employees, customers, etc., away from the traditional definition.

Traditionally, the concept of sustained yield has evolved into a very well defined model that is central to the formal education of every professional forester. This concept, simply stated, is that the objective of forest management is to achieve and maintain a uniform distribution of age classes over a given forest area such that every year the oldest age class can be harvested and that the volume of this harvest will be equal to the annual growth of the entire forest. With the same number of acres in each age class and the oldest age class harvested each year, the forest will produce an even flow of harvested timber from year to year in perpetuity. This is the simplest model of sustained yield that can be visualized best where each age class is grown separately in what is called even-aged management. The model can be easily extended to more complex situations such as unevenaged management where acre contains intermingled age classes, but only the largest or oldest trees are removed. Another extension of the model is to include the thinning or partial removals of intermediate age classes in both even and uneven-aged forests.

The age of final harvest must be precisely specified for such a forest, since there are various levels of sustained yield depending upon the age selected for final harvest. This leads to the concept of maximum sustained yield, where the selected age of the trees at final harvest maximizes the output of the forest.

In the real world, each forested ownership usually has a variety of soil conditions and other factors that make the trees grow differently. There is considerable variation in how individual trees grow within species and between species. Trees also grow differently depending on where they grow and how they are managed. They can be grown in densely stocked stands or in widely spaced stands with lots of "elbow room" to grow. They can be fertilized, irrigated or subjected to various other types of cultural practices that affect their rates of growth.

Regardless of the complexity of the forest you want to manage, or model, the computer has made today's forester equal to the task. Many computer models exist that will precisely define the maximum sustained yield level and numerous other sustained yield levels for any given forest area and the range of cultural practices and harvest ages the user wants to consider.

\section{Allowable Cut}

Actually, very few forests, if any, meet or even come close to the precise arrangement of acres or numbers of trees by age class, soil productivity, level of cultural treatments, etc., that are defined by the sustained yield model. Foresters have developed, however, a number of formulae that take a forest as it exists and move it over time toward the idealized sustained yield forest. These formulae can be very simple or very complex. The simplest formula selects the age of the trees at final harvest, such as age 50 or 100 , and then harvests $1 / 50$ th or $1 / 100$ th of the acres each year. This leads to a perfectly uniform distribution of age classes in 50 or 100 years, respectively. Some of the more complex formulae never achieve the idealized uniform age class distribution but move towards it asymptotically.

In any event, the outcome of all of these formulae is generally known as an allowable cut, which can be expressed annually or for some other time period. The essence of allowable cut calculations is that the allowable cut is a function of the forest area, the initial volume of standing timber and the growth of the forest over some specified period or until the uniform distribution of age classes has been achieved.

The US Forest Service has, since 1971, more rigidly defined sustained yield by restricting its planned harvest to no more than the long-run sustained yield of each forest. In fact, its new plans are based on something called a nondeclining yield, where there is no planned decrease in the projected harvests.

The allowable cut is like a "bag limit" on trees, and the coincidence is not accidental. The forestry profession actually began on feudal estates where the hunting of deer and boar were far more important than the harvest of timber. For centuries, peasants could help themselves to timber, but lost their heads if caught poaching the master's deer. As far as timber harvesting was concerned, the woods were treated as a commons. As timber became sufficiently scarce that it needed to be allocated to different users, the game managers became foresters by extending their "bag limits" to the trees.

The allowable cut effect is simply the change in allowable cut when the inventory or growth of a forest is changed. Adding acres, or increasing the intensity of cultural practices increases the allowable cut.

\section{Economic Analysis and Sustained Yield}

Economic analyses began to be applied to forestry in the 1800's to value forests for taxation purpose. In 1849 , Martin Faustmann, a young German forester, published a critique of the forest valuation procedures of the day, and suggested a major change (Faustmann 1849). This change was to calculate the optimal age of timber harvest using prices and interest rates. Faustmann's Formula is the first known correct application of compound interest rates in discounted cash flow analyses. Bankers and economists did not show the same level of analytical sophistication until more than 50 years later. Unfortunately, all Faustmann did was start a raging debate within the forestry profession about "soil rent" vs. "forest rent" which continues to this day. Public forest 
management agencies have almost universally rejected Faustmann's optimal harvest age calculation. So too have a few private timber companies. The disciple of the market, however, and the fact that finance managers as well as foresters get involved in private forest management decisions, has led to widespread use of Faustmann's Formula, or close approximations thereof, in the private forest sector.

A major problem still remains. All the Faustmann Formula does is define a long-run equilibrium harvest age that would produce an economic sustained yield as opposed to maximum sustained yield. In fact, maximum sustained yield harvest ages become the special case where a zero rate of interest is used in the Faustmann Formula (Gaffney 1960). Positive interest rates always lead to lower harvest ages and lower levels of inventory being carried in the long-run equilibrium forest.

Foresters and forestry organizations who adopt economic harvest ages are still strongly inclined to just plug these into their traditional allowable cut models. When the evenflow policies of most public forest management agencies are followed, the allowable cut using economic harvest ages is always lower, sometimes substantially lower, than if maximum sustained yield harvest ages are used. It's no wonder public forest management agencies have rejected Faustmann's age calculation. Partial or improper use of economics often can and does lead to more perverse results than not using economics at all.

Many public forests are managed so that existing timber inventories greatly exceed the long-run sustained yield inventory levels under either the economic or maximum yield definitions. Allowable cut calculations have resulted in the planned rationing of overmature old-growth timber inventories over more than a century to meet the evenflow constraint of not cutting more today than can be cut from the sustained yield forest of the future when the idealized uniform distribution of age classes has been achieved.

Some schools of thought even view this level of timber harvesting as "overcutting," since old-growth forests have little or no net growth. Harvesting any timber at all means that harvest exceeds the growth. The forestry profession has simply provided a more complex, but equally absurd, criteria for determining current rates of timber harvest. The naive notion that today's harvest cannot exceed today's growth is replaced with the constraint that today's harvest cannot exceed the sustained yield level of a hypothetical forest that won't exist for at least a century, if ever.

Because of the importance given these hypothetical forests to current harvest calculations, much research effort has been directed (mis-directed) into getting more insight into how much wood these hypothetical forests will grow. With the large inventories of over-mature timber and evenflow policies typical of public agencies, growth determinations for the hypothetical sustained yield forests become more important than growth in the existing forest or the transition forests, since several cycles or harvest rotations will occur before the hypothetical sustained yield forest can be created.

With all this as background, let's consider what can happen when a veneer of economic analysis is combined with sustained yield using the allowable cut effect. The results are similar to what I would expect if we put the Flat Earth Society in charge of geological surveys or the space program. follow:

A few examples of "allowable cut effect economics"

1. Assume a 500000 -acre predominately old-growth forest that currently has 6 billion board feet of timber inventory. Under current management practices, its maximum sustained yield level is 100 million board feet per year. (With Faustmann's economic harvest ages, it would only be 80 million board feet per year so this has not been seriously considered.) The annual allowable cut under sustained yield is 100 million board feet per year. Wood on the stump, or stumpage, is worth $\$ 100 / \mathrm{MBF}$. Gross annual receipts are therefore $\$ 10$ million. All management costs are $\$ 2$ million, so the net revenue is $\$ 8$ million. The present value of this net revenue stream is perpetuity when discounted with a $10 \%$ interest rate is $\$ 80$ million.

Now let's look at a more intensive forest management program that can increase the sustained yield level to 150 million board feet per year by prompt planting of cutover acres with improved trees, controlling competitive vegetation and spacing the young stands by precommercial thinning. The cost of this new program is $\$ 1.5$ million per year. Does this program make economical sense?

Annual receipts go up $\$ 5$ million for a $\$ 1.5$ million increase in annual costs. Net revenue increase from $\$ 8$ million to $\$ 11.5$ million. Net present value increases proportionately. The apparent rate of return on investment is infinite if the cash flow from increased harvests proceeds or starts at the same time as the increased cost stream. Even if the increased cost stream starts one year earlier than the revenue stream, the apparent rate of return is an astounding $300 \%$. Waiting a full decade before taking a harvest credit for the increased level of investment reduces the apparent rate of return to a more believable $15 \%$. None of these apparent rates of return mean anything. They only obfuscate the fact that economics was ignored in making the underlying forest management plans.

2. Now let's look at the same forest and a proposed land withdrawal for wilderness, a park or some other purpose. Let's assume this withdrawal would take 100000 out of the 500000 acres and 1 billion out of the 6 billion board feet inventory. The increage to be withdrawn is proportionately larger than the timber inventory to indicate lower than average productivity on the withdrawn lands. Let's further assume that the sustained yield level is reduced proportionately with the inventory from 100 million to 83.3 million board feet per year. The net annual income (assuming no change in costs) is reduced to $\$ 5.8$ million per year and the $20 \%$ net present value becomes $\$ 58.3$ million. The apparent cost of the wilderness is $\$ 21.7$ million.

3. In the interest of placating the loggers and the hikers (and not incidentally also increasing the agency budget), the forest manager might propose a "preferred alternative" that offsets the proposed withdrawal with more intensive management. The allowable cut could stay at 100 million board feet per year, the hikers would get their wilderness, the agency could increase its budget for this forest by perhaps $\$ 1$ million per year and the net revenue from the forest would drop from $\$ 8$ million to $\$ 7$ million. Net present value would drop from $\$ 80$ million to $\$ 70$ million indicating the wilderness costs only $\$ 10$ million instead of $\$ 21.7$ million.

In somewhat oversimplified form, this example illustrates what is going on today all over the United States on 197 
national forests that are in the process of producing new forest plans under an act passed by Congress in 1976. The allowable cut is no longer identified as such but has been replaced with terms like potential yield and programmed yield which explicitly tie harvest levels to the forest's budget.

A sharp analyst might point out that this forest is so overstocked in terms of current inventory that a forest fire could consume 1 billion board feet without reducing the allowable cut or the ability to harvest 100 million board feet per year in perpetuity. This analyst might also show that the intensified management program really wouldn't have to be implemented for two or three more decades for the forest to still produce 150 million board feet per year, again in perpetuity. And the most telling point this analyst might make is that the market value of this forest if it were privately owned would be over $\$ 500$ million dollars, rather than the $\$ 80$ million of the current management plan. A private owner, however, would have to adopt a totally different management plan in order to justify and generate this market value.

\section{Incompatibility of Sustained Yield and Economic Theory}

As I mentioned earlier, the sustained yield model of forest management and its trappings are incompatible with economic theory and the functioning of prices to allocate resources in competitive markets. Gross anomalies are created when anyone attempts to merge sustained yield forestry and economics and perform analyses in the spirit of compromise. Public forest management leads to resource allocations that are far inside the production possibilities frontier defined by economists as the combination of resource inputs and product outputs that are efficient for all possible sets of relative prices.

The real economic benefits of intensive management practices are totally obscured by the allowable cut effect. Many forest management practices are economically good investments if confined to particular situations, including harvest ages based on financial rather than biologic maturity and maximum physical production. The longer biologic harvest ages render most practices uneconomic.

Uneconomic traditional forest management concepts have resulted in the widespread belief by the forestry profession that forestry must be left to the state. As I mentioned earlier, this belief and the rejection of market mechanisms directly led to the establishment of the forestry profession in the United States and the creation of the National Forest System. Something similar must have happened here in Canada. Until the magic of the allowable cut effect was used to justify forestry investments, foresters generally believed that compound interest was so inimical to tree growing that private timberland owners would never practice good forestry. Socialism, rather than capitalism, was and still is the much preferred alternative among the profession for producing timber. In the western United States, including Alaska, public agencies own and manage over $68 \%$ of the total commercial forest area. This excludes parks and wilderness areas where timber production is not allowed.

The idea that competitive markets will establish prices, including interest rates and rent gradients, that will optimize the spacial and temporal production of timber has simply not penetrated the profession very far. The migratory nature of the timber industry during the 1800s was and still is mistakenly viewed as evidence of market failure. The fact that the industry was making a rational and socially desirable inventory adjustment because timber was so plentiful its price was close to zero, was and still is poorly understood. The so-called wasteful logging practices were also a function of the zero price. The widespread abandonment of cutover timberland until the 1940's reinforced the idea that industry would always cut and run. Land abandonment was caused primarily by confiscatory property tax systems that would have to be the subject of another paper.

Once the timber inventory adjustment proceeded to the point that timber prices became positive, and could be expected to rise at market rates of interest, private enterprise began to invest in successive crops of timber without benefit of allowable cut effect calculations. The fact that private owners harvest trees at much younger ages and carry much lower levels of timber inventories is still a major source of concern to public timber agencies and much of the forestry profession that measure results against the sustained yield model rather than the economic efficiency model.

\section{Alternative to Sustained Yield Model}

Only further exposure of the allowable cut effect nonsense will focus more competent economic inquiry into how forests are and ought to be managed. I'm convinced that major changes will not occur until forced upon the forestry profession by outside scrutiny. Over the past 18 years, I've given numerous presentations and written several technical papers on an economic model that has been dubbed with the acronym "ECHO" taken from EConomic Harvest Optimization (Walker 1971, 1974, 1975 \& 1978) (Johnson and Scheurman 1977).

$\mathrm{ECHO}$ is an extension of the Faustmann Formula. Faustmann developed the earliest known formula that correctly applies discounted cash flow concepts to maximize net present value. In addition to static technology and economic conditions, correct use of the Faustmann Formula requires that timberland owners face perfectly elastic factor supply and product demand curves. To apply the Faustmann Formula operationally, timberland owners must take prices as given and harvest their timber as it becomes financially mature according to the Formula regardless of the resultant fluctuation in harvests over time. Timber holdings must be so small relative to all the markets in which the owners buy and sell that none of the owners can affect prices. This condition is not met for timberland owners of any substantial size.

$\mathrm{ECHO}$ extends the net present value maximization criteria of the Faustmann Formula to application on forest ownerships that are large enough to affect prices. ECHO also permits planning assumptions about economic conditions and technology to vary with time. There is not time to go into any detail today about this model, but some of the references for this paper contain detailed discussions.

I'll conclude by presenting two charts taken directly from one of the references (Walker 1975). Figure I shows how the $\mathrm{ECHO}$ model can be used to demonstrate the economically irrational implications of even-flow policies which are very prevalent among public forest management agencies.

The two horizontal lines in Figure 1 are for two evenflow management plans based on the data presented in my PhD dissertation (Walker 1971). The lower horizontal line labeled Extensive EVENFLOW Management is based on the rotation age that maximizes the mean annual increment of 
Table 1. $6 \%$ present value of management plans (\$millions).

\begin{tabular}{lccc}
\hline & $\begin{array}{c}\text { Extensive } \\
\text { management }\end{array}$ & $\begin{array}{c}\text { Intensive } \\
\text { management }\end{array}$ & Difference \\
\hline EVENFLOW Plans & 452.3 & 524.9 & 72.6 \\
ECHO Plans & 606.0 & 607.7 & 1.7 \\
\hline
\end{tabular}

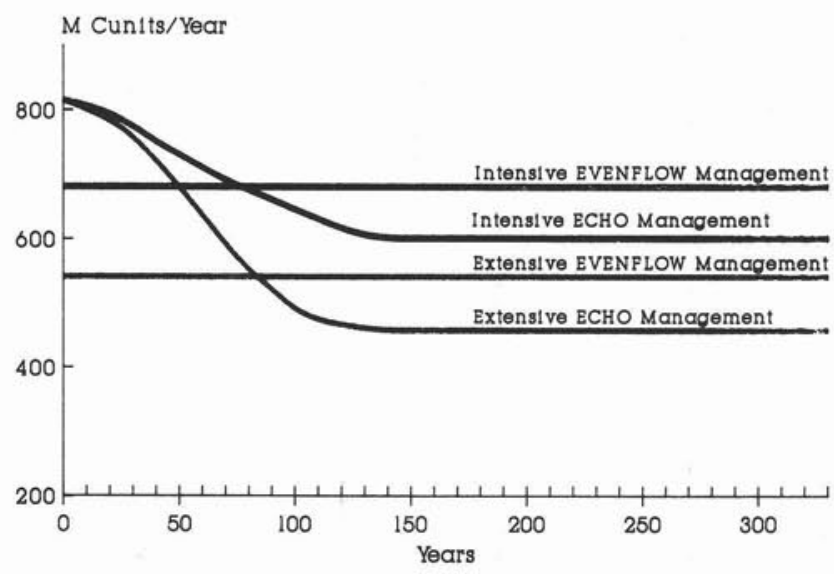

Figure 1. ECHO and even-flow harvest plans.

the yield equation. The upper horizontal line labeled Intensive EVENFLOW Management uses the same approach assuming the so-called extensive management yields can be increased by $25 \%$. The harvest in both these even-flow plans is constrained to the long-run sustained-yield level.

The two ECHO plans, however, are based on no evenflow constraint, but maximize present value based on market and physical production opportunities. The harvest schedule labeled Extensive ECHO Management is taken directly from the results provided in my dissertation. The Intensive $\mathrm{ECHO}$ Management schedule has the extensive management yields increased by $25 \%$. All the other input data for both the $\mathrm{ECHO}$ and EVENFLOW plans are identical to those used in my dissertation.

Table 1 shows the differences in the present values of the management plans corresponding to the harvest schedules shown in Figure 1. These present values are all based on a six percent rate of interest.

The EVENFLOW plans have substantially less present value than the $\mathrm{ECHO}$ plans for the same level of management. This suggests the magnitude of the opportunity costs of following an even-flow policy. This should not surprise anybody, however, since the proponents of even-flow make few pretenses that it is economically justifiable. It has become increasingly fashionable, however, to use a so-called "allowable cut effect" to justify intensive forest management practices. In this example, the "allowable cut effect" would indicate that the present value of the costs that could be incurred economically to increase yields by $25 \%$ is $\$ 72$ million. The actual value for this increased yield is only $\$ 1.7$ million. We've already discussed the irrationality of an "allowable cut effect" and need not repeat it here.

We probably could debate all day, or for several years, about whether or not ECHO plans can be called sustained yield. It would depend upon your definition. ECHO only calculates the economically optional level of harvest given a forest inventory and projected growth rates. Separate runs need to be compared to test whether the net present values contributed by any separable activity are positive or negative. If it is uneconomic to regenerate some class of land for example, or to rely only on natural regeneration as I suspect is the case in large forest areas in Canada, then so be it. Uneconomic activities should not be undertaken. If the analysis is done correctly, society will be better off without uneconomic activities than with them. The price system is simply telling us that the resources involved can be more productively employed elsewhere.

\section{References}

Faustmann, M. 1849. Calculation of the value which forest land and immature stands possess for forestry. Allgemeine Forst-und Jagd-Zeitung; pp. 441-445; (English translation edited by M. Kane entitled "Martin Faustmann and the Evolution of Discounted Cash Flow", Commonw. For. Inst. Univ. Oxford, Inst. Pap. No. 42, 1968).

Gaffney, M.M. 1960. Concepts of financial maturity of timber and other assets, NC. State College, Dept. Agric. Econ., A. E. Information Series No. 62, 105pp.

Johnson, K.N. and H.L.Scheurman 1977. Techniques for prescribing optimal timber harvest and investment under different objectives - discussion and synthesis. For Sci, Monogr 18, $31 \mathrm{p}$.

Simpson Timber Company. Undated This Is Simpson, Seattle, $14 \mathrm{pp}$

Walker, J.L. 1971. An economic model for optimizing the rate of timber harvesting. PhD dissertation, Univ. Washington, Seattle. $117 \mathrm{pp}$

Walker, J.L. 1975. ECHO - Solution technique for nonlinear economic harvest optimization model, Systems Analysis and Forest Resource Management (John Meadow, et al. eds.) Soc. Amer. For., Washington, D.C. pp. 172-188.

Walker, J.L. 1975. Managing federal timber - harvest how much, how soon? Proc. 1975 National Convention, Soc. of Am. For., Washington, D.C., pp. 78-90.

Walker, J.L. 1978. Land use planning applications of the Economic Harvest Optimization (ECHO) Model. Proc. International Union of Forest Research Organizations, Econ. Work. Group, Arnhem, The Netherlands. 